\title{
Analysis of Development Strategies of Small Enterprises
}

\author{
Yu. G Chernysheva ${ }^{1}$, G.I. Shepelenko ${ }^{2}$
}

\begin{abstract}
:
The article studies the essence of development strategies of small enterprises. It analyses the trends of developing small enterprises in Russia.

The authors discover the reasons of low increase in a number of enterprises and their economic unviability.

They suggest using tools of new analytical concept of business analysis allowing not only to assess the level of economic sustainability and business risks but also to promote its provision and to use the strategy expanding production for developing small enterprises.
\end{abstract}

Keywords: development strategies of small enterprises, development of small enterprises in Russia, business analysis of a small enterprise.

\footnotetext{
${ }^{1}$ Corresponding author, Professor of the chair of business performance analysis and forecasting, Rostov State University of Economics (RINH), e-mail: julia282001@ mail.ru ${ }^{2}$ Professor of the chair of Innovative management and entrepreneurship , Rostov State University of Economics (RINH).
} 


\section{Introduction}

The main problem connected with development strategies of small businesses, changes in planning business operations is the disbelief in its formalistic planning. Small business is commonly believed to be a skill of "bustling about", correct orientation on the market, often by instinct. Such opinion identifies insufficient attention even to midterm planning of business operations. In addition, the complexity of modern market, great flexibility of market relations requires paying more serious attention to planning.

The complexity and variety of directions of activities of economic entities claim attention to the product range on the market, availability and conditions of material, labour resources at an enterprise. To forecast the future conditions of the business an entrepreneur should know economic publications and strategic models which are necessary for making scheduled decisions.

In practice an entrepreneur deals with developing business plans while strategic planning is considered as a test. Experienced businessmen recognizing the significance of strategic governance in developing their business find out that it is much more convenient to go from strategic planning to business one, however, there is a contrary scenario in small business now. More often they implement the governance of strategic development and operation plans simultaneously. As a result, the handicap to developing prospective planning emerges: urgent operational decisions prevail over strategic issues and a small business loses perspectives in its performance.

$\checkmark$ Ideally, the process of planning production and economic activities must be continuous, i.e. there is a rolling schedule with constantly introduced changes on the market of goods, services and labour. The imperfection of Russian market has a great influence on using planning in business activity which is characterized by the following features:

$\checkmark$ continuous reforms in the area of market relations. The unpredictable consequences of these reforms reduce the scale of the planning and hinder designing the business plan of a small enterprise at least a year in advance;

$\checkmark$ a low level of capital accumulation which does not allow to make expenses on holding research for perspective planning;

$\checkmark$ the lack of legalized ethic norms regulating entrepreneurs' behavior while implementing contractual relationships.

Nowadays planning strategic development of a small enterprise is at the stage of 'instinct' entrepreneurial thinking based on the experience, talent and energy of a businessperson. Nevertheless, the consolidation of the market stability goes together with more and more preconditions for expanding business planning within the business. 


\section{Analysis of development trends of small business in Russia}

To assess the efficiency of applied development strategies it is meaningful to analyze the development trends of small business in Russia. A number of small enterprises is constantly increasing yet a number of unprofitable economic entities is growing up (Statistic Bulletin, 2015).

Table 1. A number and financial results of small business performance in Russia

\begin{tabular}{|l|l|l|l|l|l|}
\hline Indexes & 2010 & 2011 & 2012 & 2013 & 2014 \\
\hline $\begin{array}{l}\text { 1. A number of small } \\
\text { enterprises. Total, thousand } \\
\text { items }\end{array}$ & 525,4 & 495,5 & 602,7 & 1344,9 & 1530,3 \\
$\begin{array}{l}\text { Including: profitable: } \\
\text { unprofitable: }\end{array}$ & 416,2 & 402,6 & 496,0 & 1082,1 & 1212,9 \\
$\begin{array}{c}\text { 2. Financial results, mln., rub. } \\
\text { profitable: } \\
\text { unprofitable: }\end{array}$ & 108,6 & 92,9 & 106,7 & 262,8 & 310,4 \\
& 868,4 & 776,8 & 1256,2 & 20932 & 2548,6 \\
\hline
\end{tabular}

Source: Unified register of small and medium businesses. Federal tax service.

The data of Table 1 shows that the survival strategy is a topical issue for Russian business activities of small enterprises. The number of business entities has gone up 2,9 times together with the number of unprofitable ones having grown 2,9 times. In other words, a share of unprofitable organizations does not decrease and counts for about $20 \%$ of total number of small enterprises. Financial results of unprofitable small enterprises have increased four times. The condition of economic activity in individual entrepreneurship is not better.

Table 2. Registration and official termination of business activity of individual entrepreneurs

\begin{tabular}{|l|l|l|l|l|}
\hline Indexes & $2012 \Gamma$. & $2013 \Gamma$. & $2014 \Gamma$. & $2015 \Gamma$. \\
\hline $\begin{array}{l}\text { The beginning of the activity, thousand } \\
\text { people }\end{array}$ & 578,4 & 472,1 & 602,4 & 626,3 \\
$\begin{array}{l}\text { The termination of the activity, thousand } \\
\text { people }\end{array}$ & 735,0 & 965,1 & 535,5 & 419,1 \\
\hline
\end{tabular}

Source: Unified register of small and medium businesses. Federal tax service.

Table 2 shows that the number of organizations terminated their activity despite annual decrease remains significant in comparison with the number of new ones. Every three established enterprises in 2015 are equal to two terminated ones. Small business in Russia is characterized by a low number of employees per one economic entity (Table 3) (Statistic Bulletin, 2015).

Table 3. Average number of employees per one economic entity, people

\begin{tabular}{|l|l|l|l|l|l|}
\hline Indexes & 2010 & 2011 & 2012 & 2013 & 2014 \\
\hline $\begin{array}{l}\text { 1. The number of employees at } \\
\text { small enterprises, total people, }\end{array}$ & & & & & \\
\hline
\end{tabular}




\begin{tabular}{|l|l|l|l|l|l|}
\hline incl. microenterprises: & 9 & 6 & 6 & 6 & 6 \\
$\quad \begin{array}{l}\text { middle enterprises: } \\
\begin{array}{l}\text { 2. The number of employees in } \\
\text { the area of entrepreneurship } \\
\text { (on the average) }\end{array}\end{array}$ & 4 & 3 & 3 & 3 & 3 \\
\hline
\end{tabular}

Source: calculated and designed by the authors.

The data of Table 3 demonstrates in spite of the fact that the acceptable number of employees at a microenterprise must comprise up to 15 people, actual average number of workers is 5 times less and is accounted for 3 people, as a rule. Small enterprises with the acceptable accessible number up to 100 workers actually have 17 times less (about 6 people). Thus, almost all categories of small business are microenterprises. Only some hundreds small enterprises have over 15 workers.

The average number of employees at middle enterprises is gradually increasing and accounted for 121 people in 2014. The growth in 2014 compared to 2010 is $13 \%$. Such a great gap in the number of staff proves that the internal factors of economic environment in the enterprise with 3 or 6 employees and of middle enterprises with more than 120 people are inconsistent and incomparable. Therefore, the unification of such categories in MSE is unreasonable from the organizational and economic point of view.

\section{Business development strategies and the role of business analysis}

The condition of business activity in small business supposes two strategies; survival strategy and development strategy. The survival strategy is the main strategy for almost all small economic entities. The survival strategy intends to ensure the stability of business activity, to adapt to the conditions of the market and to keep the resource potential of an enterprise. The survival strategy includes production and technical, market, financial, personnel elements. Production and technical element means supporting the production on the technical level ensuring the acceptable quality of goods, works and services. Market element requires the knowledge of market conditions, directions of market relations development, accurate study of suppliers' reliability, ways of goods promotion, knowledge of advertising industry, sales promotion. Financial element is an effort to get concessions from suppliers, incentive loan rates. Personnel element stands for retaining highly-skilled staff.

Designing the survival strategy an economic entity comes up against objective limitations: cash volume and possible fund; professional skills and entrepreneur's ability to think intuitively; relationships with suppliers and distributors; competitors' counteractions, for example, decreasing the price to promote short-term demand.

Therefore, due to the low number of employees and, consequently, the volume of production great difficulties appear on the way of the struggle for the survival: little savings in the area of small business, significant influence of market environment 
factors, continuous reforms of relations between the authorities and business. These problems are deeply intertwined and augment each other. In fact, there appeared "vicious circle of small business": small-scale production - little savings - low capital investments - low efficiency - small-scale production. Designing the survival strategy, a small enterprise does not tend to use such extensive factor as the growth of production scale, but it tries to find some competitive advantages raising its economic feasibility (Liapis et al., 2013; Breckova and Havlicek, 2013; Havlicek et al., 2013.

The level of survival strategy development is mostly predetermined by the personality of the entrepreneur who estimates the profitability of a business, takes risks and responsibilities for the company performance. In small business the entrepreneur is a manager at the same time which requires professional knowledge, skills and work experience. If he meets all the requirements he can work out the survival plan of the economic entity successfully. The entrepreneur interacts with customers, suppliers, banks, local authorities; as a result, it requires appropriate behavior tactics which influence the success of the economic activity, implementing the survival strategy (Bondarenko et al., 2017).

An entrepreneur should follow the principle: "The business scale must cover the costs. If this rule is not obeyed one should revise the business strategy. If one does not manage to cover the costs within a month, one should close down the business and go to another market" (Vysokov, 2010; Vovchenko and Panasenkova, 2013; Salimova and Makolov, 2016).

The survival of a small enterprise is mostly defined by the entrepreneur's experience, his ability to analyze production and economic activity of an enterprise. It is necessary for managers of a small business to know the methodology of business analysis. To ensure the sustainable business activity it is necessary to hold business analysis as a person knowing the methodology of business analysis (analyst) should obtain flexible thinking (agile) that means the ability to apply one or another method guaranteeing the highest efficiency in every situation.

Agile perspective suggests fact response to the constant changes. The flexibility is translated into the knowledge and ability to use a range of values and principles applied in different analytical practices (methods of analyzing company performance). Business analysis suggesting the obligatory use of agile approach must constantly revise, adapt, and edit priority tasks, tactics, and methods of analysis. It must provide continuous flexibility of analytical work in case of possible changes. Analytical work cannot be done beforehand but only at exact time which guarantees its efficiency (just-in-time approach) (Features of business analysis, 2016).

Together with continuous monitoring of small business activity and, consequently, early recognition of problems or using the possibilities of further business 
development and hence ensuring the sustainable development of the organization business analysis allows to identify and analyze risks and threats and also to work out measures on its elimination, which is, especially relevant aspect in the activity of small business. The solution of these problems is possible with the help of systematic business analysis (in case of recognizing problems), since business analysis is a practice allowing to introduce changes in the organization based on identifying the needs of interested parties (stakeholders) and to develop recommendations concerning decisions which bring the profit to the interested parties (Business Analysis Body of Knowledge, 2015).

When ensuring the solvency of a small business it is obligatory to emphasize such constituent as risk. Among methods of business analysis there are methods allowing to assess risk rates which proves the rationale for its application as business analysis is aimed at providing and maintaining successful functioning of an organization, revealing possible problems preventing it.

\section{Conclusions and suggestions}

Planning the strategy development of small business is a complex interdependent process when one needs to analyze separate factors of production and economic activity of a small enterprise. The fundamental feature of the managing function of a small business involves defining the areas of efficient application of factors of external and internal environment of an economic entity using personal economic mind of an entrepreneur often based on the intuition when there is no necessary range of basic data characterizing market conditions in the definite industry, particularly possible changes in supply and demand, capital investments, forecast of price dynamics. Thanks to his abilities the entrepreneur identifies key stages of business activity, justifies the aim which will bring profit if achieved. To run business successfully, raise its solvency and reduce risks it is necessary to held business analysis allowing to ensure the justification of made managerial decisions.

We believe the aim of strategy development of small business must become the strategy of expanding the production scale in order to overcome "vicious crisis of a small business". The expansion of production volume gives the opportunity to increase the gap between revenue and expenses per a unit of product/ service. Such development strategy requires identifying personal capabilities to expand production scale, analyzing the perspectives of developing business advantages. It is also important to identify the possibilities of the influence of entrepreneurial risks on the final performance of a small enterprise.

In accordance with the strategy of expanding production scale it is necessary to work out an incentive program for the staff and also the forms of supervision encompassing the whole production and economic activity of an enterprise. 
The strategic development of a small business can be implemented only within business planning when one defines current vitality of an economic entity and its future sustainability, specifies the directions of expanding production scale in the form of qualitative and quantitative indexes of the development. Thus, it is necessary for the survival of a small business to look for internal reserves of growing production efficiency, and for its development - to expand production scale with the limited size of the enterprise. The reserves of expanding production scale are of great significance as the average number of employees at a small enterprise in the country is several times less than maximum acceptable number.

\section{References:}

Bondarenko, G.T., Isaeva, A.E., Orekhov, S.A., Soltakhanov, U.A. 2017. Optimization of the Company Strategic Management System in the Context of Economic Instability. European Research Studies Journal, 20(2B), 3-24.

Břečková, P. and Havlíček, K. 2013. Leaders Management and Personnel Controlling in SMEs. European Research Studies Journal, 16 (4), Special Issue on SMEs.

Business Analysis Body of Knowledge. 2015. URL: http://iiba.ru/chapter-1-introduction-3babok-guide/\#i-3.

Features of business analysis. 2016. Materials of regional scientific practical conference "Actual directions of the development of accounting, analysis and audit in modern economy". Rostov-on-Don: Rostov State University of Economics (RINH), 305310.

Havlíček, K., Thalassinos. I.E. and Berezkinova, L. 2013. Innovation Management and Controlling in SMEs. European Research Studies Journal, 16(4), 57-70, Special Issue on SMEs.

Liapis, K., Rovolis, A., Galanos, C. and Thalassinos, I.E. 2013. The Clusters of Economic Similarities between EU Countries: A View Under Recent Financial and Debt Crisis. European Research Studies Journal, 16(1), 41-66.

Salimova, A.T., Makolov, I.V. 2016. Unused Potential of Quality Management Systems of the Russian Companies: An Empirical Study. European Research Studies Journal, 19(3) Part A, 150-166.

Statistic Bulletin. 2015. Small and medium entrepreneurship in Russia. Rosstat, 96.

Vovchenko, G.N., Panasenkova, T. 2013. Trends of Formation the Russia's Innovation Potential. World Applied Sciences Journal, 27(10), 1362-1366.

Vysokov, V.V. 2010. Small business: Entrepreneurial universal education for schoolchildren Textbook. Rostov-on-Don, Rostov State University of Economics (RINH), 17. 